\title{
ALGUMAS BATALHAS ESTÃO SENDO PERDIDAS. PERDEREMOS A GUERRA?
}

Já conversamos neste espaço sobre as disputas ocorridas nos primeiros anos desta década a respeito dos sistemas públicos universais de saúde e da chamada cobertura sanitária universal ${ }^{1}$. O fato é que a saúde passou a ser tema de interesse na Assembleia Geral da Organização das Nações Unidas (ONU)².

Essa história começou em 2009, quando, na Organização Mundial da Saúde (OMS), foi iniciado um movimento para conter a disseminação das doenças não transmissíveis, naquele momento encabeçado pela International Diabetes Federation, pela World Heart Federation e pela Union for International Cancer Control. Tais organizações avocavam a primazia na convocação de uma cúpula das Nações Unidas sobre as doenças não transmissíveis. Começava, então, o debate mais acirrado entre aqueles que defendiam a simples extensão da cobertura de serviços de assistência médica e os detratores dessa ideia, que afirmavam que tal solução não seria capaz de atender aos muitos outros programas de saúde pública, indispensáveis para assegurar "uma visão mais ampla, com um conjunto de objetivos com metas e indicadores de prevenção, tratamento, determinantes sociais, sistemas de saúde, mudanças climáticas e equidade, entre outras preocupações"'. (Tradução livre.) Assim, os argumentos variaram da necessidade de "estabelecer e estimular uma agenda sanitária global para o acesso universal a medicamentos e bens de saúde. [...] sublinhando o importante papel dos medicamentos genéricos na realização do direito à saúde" (tradução livre), até a afirmação de que os programas de ajuste, levando os governos a diminuir gastos públicos e ao desenvolvimento de um setor privado que visa ao lucro, dentro de uma lógica de mercado, não produziriam "saúde". Esse debate permeou a 67ª Sessão Plenária da Assembleia Geral

\footnotetext{
${ }^{1}$ DALLARI, Sueli Gandolfi. Editorial. Revista de Direito Sanitário, São Paulo, v. 13, n. 2, p. 7-9, out. 2012. Disponível em: <http://www.revistas.usp.br/rdisan/article/view/56225/59437>. Acesso em: 15 nov. 2017. http://dx.doi.org/10.11606/issn.2316-9044.v13i2p7-9 e Id. Editorial. Revista de Direito Sanitário, São Paulo, v. 14, n. 1, p. 7-10, jun. 2013. Disponível em: <http://www.revistas.usp.br/rdisan/ article/view/56620/59637>. Acesso em: 15 nov. 2017. http://dx.doi.org/10.11606/issn.2316-9044. v14i1p7-10.

${ }^{2}$ UNGA. Political Declaration of the High-level Meeting on the Prevention and Control of Non-communicable Diseases. Sixty-sixth session. Disponível em: <http://www.un.org/en/ga/ncdmeeting2011/>

${ }^{3}$ HORTON, R. Offline: the advantages of Universal Health. The Lancet, v. 380, n. 9854, p. 1632 , 10 Nov. 2012. Acesso em 13 out. 2017. Disponível em: <http://www.thelancet.com/action/showFullTextlmages?pii =S0140-6736\%2812\%2961932-1>. http://dx.doi.org/10.1016/S0140-6736(12)61932-1.

${ }^{4} \mathrm{No}$ original: "We agree to establish and encourage a global health agenda for universal access to affordable medicines and health commodities." [...] we underlined the important role of generic medicines in the realization of the right to health." BRICS Health Ministers' Meeting -- Beijing Declaration (11 July 2011). Disponível em: <http://brics.itamaraty.gov.br/press-releases/21-documents/167-brics-health-ministers-meeting>. Acesso em: 13 out. 2017.
} 
da ONU, que terminou aprovando um documento de consenso que encorajava os governos a planejar ou prosseguir a transição para o acesso universal a serviços de saúde acessíveis e de qualidade ${ }^{5}$.

Entretanto, no ambiente de construção dos novos objetivos do milênio ${ }^{6}$, é possível perceber a repartição dos interesses entre os defensores da resposta às doenças não transmissíveis e aqueles que agora claramente defendem a cobertura sanitária universal. Na revisão da ONU sobre as doenças não transmissíveis, evoluiu-se para o reconhecimento da necessidade de comprometimento e atuação no nível dos Estados-Membros. Além disso, ao ser adotada a Agenda 2030 para o desenvolvimento sustentável, o objetivo $3^{\circ}$ - "Assegurar uma vida saudável e promover o bem-estar para todos, em todas as idades." - incluiu a redução de um terço da mortalidade prematura por doenças não transmissíveis por meio da prevenção e do tratamento a ser verificada no coeficiente atribuído à doença cardiovascular, ao câncer, à diabetes ou à doença respiratória crônica (meta e indicadores 3.4.1 ${ }^{8}$ ).

Por outro lado, foi criado um grupo de pressão que reivindicava, na $65^{\mathrm{a}}$ Sessão do Comitê Regional da 52a Reunião do Conselho Diretor da Organização Pan-Americana de Saúde, ser necessário "priorizar o acesso universal à saúde, entendida como a garantia do direito à saúde, respondendo não apenas à cobertura dos serviços de saúde, mas também às intervenções nos determinantes sociais da saúde, como o objetivo prioritário a ser apresentado na Agenda de Desenvolvimento pós2015. Propõe-se, também, [...] impulsionar a cobertura universal, que deve incluir o acesso a todas as intervenções importantes, e fortalecer os sistemas de saúde, como metas" ". A Agenda 2030 para o desenvolvimento sustentável, no mesmo objetivo $3^{\circ}$, definiu como meta e indicadores: "alcançar a cobertura sanitária universal, incluindo a proteção do risco financeiro, o acesso aos serviços essenciais de atenção à saúde

\footnotetext{
${ }^{5}$ UNITED NATIONS. General Assembly. GA/11326. Adopting consensus text, General Assembly encourages member states to plan, pursue transition of national health care systems towards universal coverage. Dec 12, 2012. Disponível em: <https://www.un.org/press/en/2012/ga11326.doc.htm>.

${ }^{6} \mathrm{Na}$ Assembleia Geral da ONU, em 2014, foi apresentada a proposta - discutida no Intergovernmental Negotiations on the Post 2015 Development Agenda (IGN), entre janeiro e agosto de 2015 - e a Agenda 2030 para o desenvolvimento sustentável, denominada "Transformando nosso mundo" em setembro de 2015. UNITED NATIONS. Disponível em: <https://www.un.org/ga/search/view_doc.asp?symbol=A/ RES/70/1\&Lang=E>. Acesso em: 13 out. 2017..

${ }^{7}$ BRASIL. Ministério das Relações Exteriores. Transformando Nosso Mundo: a Agenda 2030 para o Desenvolvimento Sustentável. Disponível em: <http://www.itamaraty.gov.br/images/ed_desenvsust/ Agenda2030completoportugus12fev2016.pdf >. Acesso em: 13 out. 2017.

8UNITED NATIONS. General Assembly. Resolution adopted by the General Assembly on 6 July 2017. Seventyfirst session. Disponível em: <https://undocs.org/A/RES/71/313>. Acesso em: 13 out. 2017.

${ }^{9}$ ORGANIZAÇÃO PAN-AMERICANA DA SAÚDE. ORGANIZAÇÃO MUNDIAL DA SAÚDE. $52^{\circ}$ Conselho Diretor. $65^{\circ}$ Sessão do Comitê Regional. Os objetivos de desenvolvimento do milênio e as metas de saúde na região das américas. Disponível em: <https://www.google.com.br/url?sa=t\&rct=j\&q=\&esrc=s\&source=web\&cd=10\&c ad=rja\&ved=0CJcBEBYwCQ\&url=http\%3A\%2F\%2Fwww.paho.org\%2Fhq\%2Findex.php\%3Foption\%3Dcom docman\%26task\%3Ddoc_download\%26gid\%3D22651\%26ltemid\%3D270\%26lang\%3Dpt\&ei=hLw6UuanO 9004AP8rYGYCg\&usg=AFQjCNHLO_abVXBi-p6Q2_R4IOph8D9EvA\&sig2=8SZtfn6I14ytFkUzj2fP_g\&bvm=bv .52288139 ,d.dmg>. Acesso em: 13 out. 2017.
} 
de qualidade e o acesso aos medicamentos e vacinas seguros, efetivos, de qualidade e economicamente acessíveis para todos", verificáveis pela "cobertura dos serviços de saúde essenciais (definida como a cobertura média de serviços essenciais baseada em intervenções traçadoras que incluem saúde reprodutiva, materna, neonatal e infantil, doenças infecciosas, doenças não transmissíveis e capacidade e acesso aos serviços para a população geral e para as mais desfavorecidas)", além do "número de pessoas cobertas por seguro de saúde ou um sistema de saúde pública por 1.000 habitantes" (meta e indicadores 3.8.1 e 3.8.2) ${ }^{10}$.

Hoje, parece que aquela repartição de interesses está se transformando em disputa aberta. Curiosamente, o mesmo editor que defendia a necessidade de adoção de um sistema universal de saúde que possibilitasse, inclusive, a consideração dos determinantes sociais para uma organização mais abrangente das ações e dos serviços de saúde, agora acusa o novo diretor geral da OMS, Tedros Adhanom Ghebreyesus, de - ao contrário de sua antecessora, que assinalou a crescente importância das doenças não transmissíveis, destinadas a remodelar a face da saúde pública - ignorar as doenças não transmissíveis na eleição de suas prioridades. E complementa: "Há pouco dinheiro disponível. Os sistemas de saúde ainda são muito fracos para dispensar serviços de qualidade. Ninguém foi capaz de articular como as doenças não transmissíveis cabem na convocação para a cobertura universal em saúde"11. (Tradução livre.)

Os defensores dos sistemas universais de saúde, no entanto, ainda "não jogaram a toalha". Com efeito, em setembro foi lançado um plano, capitaneado pelo senador Bernie Sanders (candidato às últimas prévias do Partido Democrata às eleições presidenciais nos Estados Unidos da América) e subscrito por mais 16 senadores, que propõe o Universal Medicare Program (UMP). Trata-se de um sistema de pagador único que acaba com o mercado dos planos de saúde e proíbe os seguradores privados, assegurando o mesmo atendimento hoje previsto no Affordable Care Act (ACA), conhecido como o 'Obama Care', mas eliminando os co-pagamentos e as deduções e cobrindo tanto os cidadãos estadunidenses quanto os imigrantes com e sem documentos de todas as idades. Os proponentes veem o plano como a ponte ideal para alcançar a cobertura sanitária universal ${ }^{12}$.

\footnotetext{
${ }^{10}$ UNITED NATIONS. General Assembly. Resolution adopted by the General Assembly on 6 July 2017. Disponível em: <https://undocs.org/A/RES/71/313>. Acesso em: 13 out. 2017.

${ }^{11}$ No original "There is little money available. Health systems are still too weak to deliver quality services. Nobody has been able to articulate how NCDs fit into the call for universal health coverage." HORTON, R. NCDs: Why are we failing? The Lancet, v. 390, n. 10092, p. 346, July 22, 2017. Disponível em: <http://www. thelancet.com/journals/lancet/article/PIIS0140-6736(17)31919-0/fulltext>. Acesso em: 13 out. 2017. http://dx.doi.org/10.1016/S0140-6736(17)31919-0.

1217 SENATORS Introduce Medicare for All Act. Wednesday, September 13, 2017. Disponível em: <https:// www.sanders.senate.gov/newsroom/press-releases/17-senators-introduce-medicare-for-all-act>. Acesso em: 13 out. 2017.
} 
A convocatória para a Conferência Global da OMS sobre as doenças não transmissíveis, que se realizará em Montevidéu entre os dias 18 e 20 de outubro deste ano, assinada pelo Presidente do Uruguai, Tabaré Vázquez, e pelo diretor geral da OMS - apesar de começar apresentando a lista das ações testadas pela organização para melhorar a prevenção, a detecção precoce e o tratamento de tais doenças com "a priorização da lista de medicamentos essenciais, o aconselhamento e o cuidado

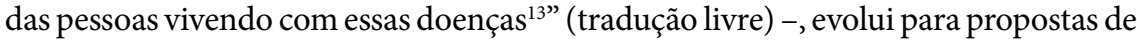
ações regulatórias. O texto conclui afirmando que os governos protegerão a saúde de seus povos implementando essas medidas e que, "quando implementarem a taxação do tabaco, das bebidas açucaradas e do álcool, eles gerarão a renda que poderá ser reinvestida na cobertura sanitária universal"14 (tradução livre).

Portanto, verifica-se que, no panorama internacional, as primeiras batalhas para a generalização de sistemas públicos universais de saúde sofreram derrotas importantes, tendo prevalecido a compreensão muito mais limitada de cobertura sanitária universal. Trata-se, agora, de lutar pela mais ampla interpretação da expressão vencedora, como fizeram alguns acadêmicos que acabam de publicar o resultado de uma mesa-redonda sobre cobertura sanitária universal, estabelecimento de prioridades e direitos humanos. Eles sugerem três passos para que os Estados sigam nessa direção: (a) que os planejadores e os legisladores e juízes compreendam que estabelecer prioridades não significa apenas maximizar os benefícios e que o direito à saúde não implica assegurar a cada indivíduo o acesso a qualquer cuidado de saúde independentemente do custo; (b) quando princípios materiais e procedimentais para assegurar uma alocação de recursos razoável houverem sido estabelecidos por meio de processos participativos e transparentes, os Estados devem institucionalizar as prioridades deles decorrentes; (c) quando uma interpretação razoável a respeito do conteúdo do direito à saúde for clareada sob a lei nacional, respeitando os princípios citados, os ministros das finanças devem adequar o orçamento considerando as obrigações estatais para a garantia desse direito ${ }^{15}$.

No Brasil parece que as derrotas têm sido ainda mais desmoralizantes, uma vez que partimos da definição constitucional de um sistema público universal de saúde e vemos crescentes ameaças a sua sustentação. Certamente as questões

\footnotetext{
${ }^{13}$ No original: “[...] prioritising essential medicines, counselling, and care for people living with an NCD." GHEBREYESUS, Tedros Adhanom; RAMÓN VÁZQUEZ, Tabaré. Beating NCDs can help deliver universal health coverage. Disponivel em: <http://www.who.int/mediacentre/commentaries/ncds-universalcoverage/en/>. Acesso em: 13 out. 2017.

${ }^{14}$ No original: "Taxing tobacco, alcohol, and sugary drinks not only curbs consumption of unhealthy products, it can also generate revenue for disease prevention and treatment." GHEBREYESUS, Tedros Adhanom; RAMÓN VÁZQUEZ, Tabaré. op. cit.

${ }^{15}$ RUMBOLD, B. et al. Universal health coverage, priority setting, and the human right to health. The Lancet, v. 390, n. 10095, p. 712-4, Aug. 12, 2017. Disponível em: <http://www.thelancet.com/journals/lancet/article/ PIIS0140-6736(17)30931-5/fulltext>. Acesso em: 13 out. 2017. 10.1016/S0140-6736(17)30931-5.
} 
ligadas à chamada "judicialização da saúde” exigem que apreciemos com serenidade os argumentos levantados pelos acadêmicos na mesa-redonda acima citada. Faltam-nos acordos a respeito de cada um dos passos propostos que, sem dúvida, são indispensáveis para a plena realização da saúde enquanto direito de todos. Por outro lado, gastar a energia governamental na introdução de mecanismos para assegurar o mercado dos planos de saúde e estimular os seguradores privados - como é o caso da proposta dos chamados "planos acessíveis"16 - representa um contrassenso.

Mas, sobretudo, não se pode aceitar o retrocesso na garantia do direito à saúde representado pela Emenda Constitucional n. 86/2015 ${ }^{17}$. Não há dúvida de que o Brasil assumiu o dever de implementação progressiva dos direitos no nível máximo de recursos disponíveis, conforme o artigo $2^{\circ}$, item 1 do Pacto Internacional sobre Direitos Econômicos, Sociais e Culturais (promulgado pelo Decreto n. 591/1992 ${ }^{18}$ ). Assim como não está em disputa o fato de que o Brasil assumiu também a obrigação de adotar medidas até o máximo da disponibilidade orçamentária, inscrita no artigo $1^{\circ}$ do Protocolo Adicional à Convenção Americana sobre Direitos Humanos em matéria de Direitos Econômicos, Sociais e Culturais, também conhecido como Protocolo de São Salvador (promulgado pelo Decreto n. 3.321/1999 ${ }^{19}$ ). Além disso, a partir de 2015, com a vigência das novas regras postas pela EC n. 86/2015, houve um corte considerável nas verbas alocadas para a saúde - de R \$11,7 bilhões em relação a 2014 e de $\mathrm{R} \$ 2,5$ bilhões em relação a 2015. Ora, as perdas nominais nos primeiros exercícios subsequentes à promulgação da referida emenda evidenciam a inconstitucionalidade da medida - por ter reduzido, em termos nominais, o valor de um exercício financeiro para o outro. Essa redução foi vedada expressamente pela Lei Complementar n. $141 / 2012^{20}$ (artigo $5^{\circ}$, parágrafo $2^{\circ}$ ), que regulamentou o

${ }^{16}$ AGÊNCIA NACIONAL DE SAÚDE COMPLEMENTAR - ANS. Relatório descritivo do GT de planos acessíveis. Relatório de consolidação das informações e contribuições ao Projeto de Plano de Saúde Acessível. Rio de Janeiro, 22 de agosto de 2017. Disponivel em: <http://www.ans.gov.br/images/stories/noticias/pdf/ VERS\%C3\%830_FINAL_RELATORIO_DESCRITIVO_GT_ANS_PROJETO_PLANO_DE_SAUDE_ACESSIVEL_ FINAL_.pdf>.

${ }^{17}$ BRASIL. Emenda Constitucional n. 86, de 17 de março de 2015. Altera os arts. 165, 166 e 198 da Constituição Federal, para tornar obrigatória a execução da programação orçamentária que especifica. Disponível em: <http://www.planalto.gov.br/ccivil_03/constituicao/emendas/emc/emc86.htm>. Acesso em: 13 out. 2017.

${ }^{18}$ BRASIL. Decreto n. 591, de 6 de julho de 1992. Atos Internacionais. Pacto Internacional sobre Direitos Econômicos, Sociais e Culturais. Promulgação. Disponível em: <http://www.planalto.gov.br/ccivil_03/ decreto/1990-1994/d0591.htm>. Acesso em: 13 out. 2017.

${ }^{19}$ BRASIL. Decreto n. 3.321, de 30 de dezembro de 1999. Promulga o Protocolo Adicional à Convenção Americana sobre Direitos Humanos em Matéria de Direitos Econômicos, Sociais e Culturais "Protocolo de São Salvador", concluído em 17 de novembro de 1988, em São Salvador, El Salvador. Disponível em: <http://www.planalto.gov.br/ccivil_03/decreto/d3321.htm>. Acesso em: 13 out. 2017.

${ }^{20}$ BRASIL. Lei Complementar n. 141, de 13 de janeiro de 2012. Regulamenta o § $3^{\circ}$ do art. 198 da Constituição Federal para dispor sobre os valores mínimos a serem aplicados anualmente pela União, Estados, Distrito Federal e Municípios em ações e serviços públicos de saúde; estabelece os critérios de rateio dos recursos de transferências para a saúde e as normas de fiscalização, avaliação e controle das despesas com saúde nas 3 (três) esferas de governo; revoga dispositivos das Leis ns 8.080, de 19 de setembro de 1990, e 8.689, de 27 de julho de 1993; e dá outras providências. Disponível em: <http://www.planalto.gov.br/ ccivil_03/leis/LCP/Lcp141.htm>. Acesso em: 13 out. 2017. 
artigo 198, parágrafo $2^{\circ}$, inciso I, da Constituição Federal de $1988^{21}$ - que estabelece que os percentuais mínimos a serem aplicados anualmente pela União em ações e serviços públicos de saúde seriam definidos por meio de lei complementar. Uma alvissareira vitória nessa batalha foi a concessão da medida cautelar na ação direta de inconstitucionalidade (ADIn 5.59522) relatada pelo Ministro Ricardo Lewandowski, afirmando que as alterações introduzidas pela EC n. 86/2015 no financiamento mínimo do direito à saúde "inegavelmente constrangem a estabilidade jurídica e o caráter progressivo do custeio federal das ações e serviços públicos de saúde”.

Será lamentável que, tendo conseguido fixar o objetivo almejado, comecemos a ceder terreno e a perder batalhas desnecessárias. Sabemos aonde queremos chegar, não percamos o plano de rota: queremos um sistema público universal de saúde capaz de garantir o direito à saúde para todos!

Sueli Gandolfi Dallari

Editora científica

${ }^{21}$ BRASIL. Constituição da República Federativa do Brasil de 1988. Disponível em: <http://www.planalto.gov. br/ccivil_03/constituicao/constituicaocompilado.htm>. Acesso em: 13 out. 2017.

${ }^{22}$ SUPREMO TRIBUNAL FEDERAL. ADI 5595 - Ação Direta de Inconstitucionalidade. Disponível em: <http:// www.stf.jus.br/portal/processo/verProcessoAndamento.asp?incidente=5056708>. Acesso em: 15 nov. 2017. 


\section{SOME BATTLES ARE BEING LOST. WILL WE LOOSE THE WAR?}

We have already talked here about the disputes of the first years of this decade about the universal public health systems and the so-called universal coverage health plans $^{1}$. In fact, health became a subject of interest in the General Assembly of the United Nations (UN) ${ }^{2}$.

This story begun in 2009, when in the World Health Organization (WHO), a movement started to restrain the spreading of noncommunicable diseases, leaded at that time by the International Diabetes Federation, by the World Heart Federation and by the Union for International Cancer Control. These organizations advocated for the primacy in the convocation of a summit of the United Nations about noncommunicable diseases. Then started the most fierce debate between those who stood up for the simple extension of the medical care services coverage and the detractors of this idea, who asserted that such a solution would not be enough to provide for the many other public health programs, indispensable to guarantee a "a wider vision, with a set of objectives, goals and prevention indicators, treatment, social determinants, health systems, climate change and equity, among other concerns"3. Thus, the arguments stretched from the need for “[...] establish and encourage a global health agenda for universal access to affordable medicines and health commodities. [...] we underlined the important role of generic medicines in the realization of the right to health" ${ }^{\text {, }}$, to the statement that the adjustment programs, leading governments to reduce public spending and the development of a private sector that pursues profit, within a logic based on the market, would not produce "health". This debate pervaded the $67^{\text {th }}$ Plenary Session of the United Nations, which ended up approving a consensus document encouraging governments to plan or proceed to the transition to universal, accessible and good quality health services ${ }^{5}$.

\footnotetext{
${ }^{1}$ DALLARI, Sueli Gandolfi. Editorial. Revista de Direito Sanitário, São Paulo, v. 13, n. 2, p. 7-9, out. 2012. Available at: <http://www.revistas.usp.br/rdisan/article/view/56225/59437>. Date accessed: 15 Nov. 2017. http:// dx.doi.org/10.11606/issn.2316-9044.v13i2p7-9 e Id. Editorial. Revista de Direito Sanitário, São Paulo, v. 14, n. 1, p. 7-10, jun. 2013. Availabe at: <http://www.revistas.usp.br/rdisan/article/view/56620/59637>. Date accessed: 15 Nov. 2017. http://dx.doi.org/10.11606/issn.2316-9044.v14i1p7-10.

${ }^{2}$ UNGA. Political Declaration of the High-level Meeting on the Prevention and Control of Non-communicable Diseases. Sixty-sixth session. Available at: <http://www.un.org/en/ga/ncdmeeting2011/>. Date accessed: 15 Nov. 2017.

${ }^{3}$ HORTON, R. Offline: the advantages of Universal Health. The Lancet, v. 380, n. 9854, p. 1632, 10 Nov. 2012. Available at: <http://www.thelancet.com/action/showFullTextImages?pii=S0140-6736\%2812\%2961932-1>. Date accessed: 15 Nov. 2017. http://dx.doi.org/10.1016/S0140-6736(12)61932-1.

${ }^{4}$ BRICS Health Ministers' Meeting - Beijing Declaration (11 July 2011). Available at: <http://brics.itamaraty.gov.br/ press-releases/21-documents/167-brics-health-ministers-meeting>. Date accessed: 13 Oct. 2017.

${ }^{5}$ UNITED NATIONS. General Assembly. GA/11326. Adopting consensus text, General Assembly encourages member states to plan, pursue transition of national health care systems towards universal coverage. Dec 12, 2012. Available at: <https://www.un.org/press/en/2012/ga11326.doc.htm>. Date accessed: 13 Oct. 2017.
} 
Meanwhile, in the environment where new objectives for the millennium are created ${ }^{6}$, it is possible to realize the division of interests among the advocates of the response to noncommunicable diseases and those who now clearly stand for universal health coverage. In the UN review about noncommunicable diseases, the realization was achieved of the need of commitment and action among the Member States. Besides, when adopting the 2030 Agenda for sustainable development, the $3^{\text {rd }}$ objective - "Ensuring healthy lives and promoting the well-being for all at all ages." noncommunicable diseases through prevention and treatment, to be verified with the coefficient attributed to cardiovascular disease, cancer, diabetes or to chronic respiratory disease (goal and indicators $3 \cdot 4 \cdot 1^{8}$ ).

On the other hand, a pressure group was created that, in the $65^{\text {th }}$ Regional Committee Session of the $52^{\text {nd }}$ Meeting of the Directing Council of the Pan American Health Organization, claimed the need to "prioritize de universal access to health, understood as a guarantee of the right to health, responding not only to health service coverage, but also to the intervention in the health social determinants, as a priority objective to be addressed in the Development Agenda post 2015. It is also proposed, [...] to bolster universal coverage, that should include, as goals, the access to all mayor interventions, and the strengthening of the health systems." ${ }^{\prime 9}$ The 2030 Agenda for sustainable development, also on the $3^{\text {rd }}$ objective, defined as a goal and indicators: "to reach universal health coverage, including the protection against financial risk, the access to essential good quality medical care services and to safe, effective and good quality medicines and vaccines, that are economically viable for all", verifiable through "essential health services coverage (defined as the average coverage of essential services based on tracer interventions that include reproductive, maternal, neonatal and child health, infectious diseases, noncommunicable diseases and service capacity and access of the general and the most disadvantaged

\footnotetext{
${ }^{6}$ In the UN General Assembly of 2014, a proposal was presented - and discussed in the Intergovernmental Negotiations on the Post 2015 Development Agenda (IGN), between January and August 2015 - and the 2030 Agenda for sustainable development, denominated "Transforming our World" in September 2015. Available at: <https://www.un.org/ga/search/view_doc.asp?symbol=A/RES/70/1\&Lang=E>. Date accessed: 13 Oct. 2017.

${ }^{7}$ BRASIL. Ministério das Relações Exteriores. Transformando Nosso Mundo: a Agenda 2030 para o Desenvolvimento Sustentável. Available at: <http://www.itamaraty.gov.br/images/ed_desenvsust/ Agenda2030completoportugus12fev2016.pdf > . Date accessed: 13 Oct. 2017.

8 UNITED NATIONS. General Assembly. Resolution adopted by the General Assembly on 6 July 2017. Seventyfirst session. Available at: <https://undocs.org/A/RES/71/313>. Date accessed: 13 Oct. 2017.

${ }^{\circ}$ ORGANIZAÇÃO PAN-AMERICANA DA SAÚDE. ORGANIZAÇÃO MUNDIAL DA SAÚDE. $52^{\circ}$ Conselho Diretor. $65^{\circ}$ Sessão do Comitê Regional. Os objetivos de desenvolvimento do milênio e as metas de saúde na região das américas. Available at: <https://www.google.com.br/url?sa=t\&rct=j\&q=\&esrc=s\&source=web\&cd=10\&ca $\mathrm{d}=$ rja\&ved=0CJcBEBYwCQ\&url=http\%3A\%2F\%2Fwww.paho.org\%2Fhq\%2Findex.php\%3Foption\%3Dcom_ docman\%26task\%3Ddoc_download\%26gid\%3D22651\%26Itemid\%3D270\%26lang\%3Dpt\&ei=hLw6Uuan 09004AP8rYGYCg\&usg=AFQjCNHLO_abVXBi-p6Q2_R4IOph8D9EvA\&sig2=8SZtfn6I14ytFkUzj2fP_g\&bvm $=$ bv.52288139,d.dmg>. Date accessed: 13 Oct. 2017.
} 
population)", besides the "number of people covered by health insurance or a public health system every 1,000 inhabitants" (goal and indicators 3.8.1 and 3.8.2) ${ }^{10}$.

Today, it seems like that division of interests is becoming an open dispute. Curiously, the same editor who supported the adoption of a universal health system that would also contemplate the social determinants for a larger organization of actions and health services, now accuses the new Director General of the WHO, Tedros Adhanom Ghebreyesus of ignoring the noncommunicable diseases in the choice of his priorities - as opposed to his predecessor, who asserted the importance of noncommunicable diseases, intended to reshape the face of public health. And adds: "There is little money available. Health systems are still too weak to deliver quality services. Nobody has been able to articulate how NCDs fit into the call for universal health coverage"."

However, the advocates of the universal health systems have not yet "thrown in the towel". In fact, in September, a plan was launched, leaded by Senator Bernie Sanders (candidate in the last primary elections of the Democratic Party, for the presidential election in the United States of America) and subscribed for another 16 senators, who proposes the Universal Medicare Program (UMP). This is a single payer system that ends health insurance market and forbids the private insurers, ensuring the same health care currently provided by the Affordable Care Act (ACA), known as "Obama Care", but eliminating the co-payments and the deductions and covering both the American citizens and the immigrants, documented or not, at all ages. The proponents see this plan as an ideal bridge to reach the universal health coverage ${ }^{12}$.

The convocation to the WTO Global Conference about noncommunicable diseases, that will take place in Montevideo between 18 and 20 of October this year, signed by the President of Uruguay, Tabaré Vázquez, and by the director general of the WHO - starts with a list of actions tested by the organization to improve prevention, early detection and treatment of such diseases by "[...] prioritising essential medicines, counselling, and care for people living with an NCD." ${ }^{13}$ In spite of that, it evolves to the proposition of regulatory actions. The text ends assenting that the governments will protect the health of their peoples by implementing these measures and that "Taxing tobacco, alcohol, and sugary drinks not only curbs consumption

\footnotetext{
10UNITED NATIONS. General Assembly. Resolution adopted by the General Assembly on 6 July 2017. Available at: <https://undocs.org/A/RES/71/313>. Date accessed: 13 Oct. 2017.

${ }^{11}$ HORTON, R. NCDs: Why are we failing? The Lancet, v. 390, n. 10092, p. 346, July 22, 2017. Available at: $\quad$ <http://www.thelancet.com/journals/lancet/article/PIIS0140-6736(17)31919-0/fulltext>. Date accessed: 13 Oct. 2017. http://dx.doi.org/10.1016/S0140-6736(17)31919-0.

1217 SENATORS Introduce Medicare for All Act. Wednesday, September 13, 2017. Available at: <https:// www.sanders.senate.gov/newsroom/press-releases/17-senators-introduce-medicare-for-all-act $>$. Date accessed: 13 Oct. 2017.

${ }^{13}$ Id. Ibid.
} 
of unhealthy products, it can also generate revenue for disease prevention and treatment." ${ }^{14}$

Therefore, it is evident that in the international scene, the first battles for the generalization of universal public health systems experienced important defeats, prevailing a much narrower understanding of what a universal health system is. It is now a question of struggling for a wider interpretation of the winning expression, as some scholars did and just published the results of a round table about universal health coverage, determination of priorities and human rights. They suggest three steps that States should take to proceed in this direction: (a) planners, legislators and judges should understand that setting priorities does not mean to maximize benefits and that the right to health does not imply to give access to every individual to any health care service regardless the cost; (b) once material and procedural principles that ensure the reasonable allocation of resources have been established, through participative and transparent processes, the States must institutionalize the priorities thus originated; (c) once a rational interpretation regarding the contents of the right to health is clearly stated under the national law, respecting the above principles, the finance ministers must adjust their budgets considering the state obligation to guarantee this right ${ }^{15}$.

In Brazil the defeats seem to be even more disheartening, because we departed from a constitutional definition of a universal public health system and see increasing threats to its sustenance. Certainly, the question connected with the so-called "judicialization of health" demands that we examine with serenity the arguments raised by the scholars in the round-table mentioned above. We lack agreements on every one of the proposed steps that, undoubtedly, are indispensable for the full realization of health as a right of all. On the other hand, the spend governmental energy in the introduction of mechanisms to ensure the health insurance market and stimulate the private insurers - as is the case with the proposition of the so-called "accessible plans"16 - is plain nonsense.

However, above all, it is not possible to accept a retrograde step in the guarantee of the right to health represented by the Constitutional Amendment no. $86 / 2015^{17}$. There is no doubt that Brazil undertook the obligation of the progressive

\footnotetext{
${ }^{14}$ GHEBREYESUS, Tedros Adhanom; RAMÓN VÁZQUEZ, Tabaré. op. cit.

${ }^{15}$ RUMBOLD, B. et al. Universal health coverage, priority setting, and the human right to health. The Lancet, v. 390, n. 10095, p. 712-4, Aug. 12, 2017. Available at: <http://www.thelancet.com/journals/lancet/article/ PIIS0140-6736(17)30931-5/fulltext>. Date accessed: 13 Oct. 2017. http://dx.doi.org/10.1016/S01406736(17)30931-5.

${ }^{16}$ AGÊNCIA NACIONAL DE SAÚDE COMPLEMENTAR - ANS. Relatório descritivo do GT de planos acessíveis. Relatório de consolidação das informações e contribuições ao Projeto de Plano de Saúde Acessível. Rio de Janeiro, 22 de agosto de 2017. Available at: <http://www.ans.gov.br/images/stories/noticias/pdf/ VERS\%C3\%830_FINAL_RELATORIO_DESCRITIVO_GT_ANS_PROJETO_PLANO_DE_SAUDE_ACESSIVEL_ FINAL__.pdf>. Date accessed: 13 Nov. 2017.

${ }^{17}$ BRASIL. Emenda Constitucional n. 86, de 17 de março de 2015. Amends the articles 165, 166 and 198 of the Federal Constitution, to turn into mandatory the execution of the specified budget program. Available at: <http:// www.planalto.gov.br/ccivil_03/constituicao/emendas/emc/emc86.htm>. Date accessed: 13 Oct. 2017.
} 
implementation of rights up to the maximum available resources, as per article $2^{\circ}$, item 1 of the International Covenant on Economic, Social and Cultural Rights (promulgated by Decree no. 591/1992 ${ }^{18}$ ). As there is not dispute over the fact that Brazil also committed to adopting measures to the maximum budget availability, inscribed on article $1^{\circ}$ of the Additional Protocol to the American Convention of Human Rights in the Area of Economic, Social and Cultural Rights, also known as the Protocol of San Salvador (promulgated by Decree no. 3.321/1999 ${ }^{19}$ ). Besides, as of 2015, with the new rules enforced by the EC no. 86/2015, there was a considerable reduction in the sums allocated for health - from $\mathrm{R} \$ 11.7$ billion in relation to 2014 and $\mathrm{R} \$ 2.5$ billion in relation to 2015. Now, the nominal losses on the first financial years after the promulgation of this amendment reveal the unconstitutionality of this measure - for having reduced, in nominal terms, the value of one financial year to the other. This reduction was expressly prohibited by the Complementary Law no. $141 / 2012^{20}\left(5^{\text {th }}\right.$ article, $\left.\$ 2^{\circ}\right)$, that regulated article 198, $₫ 2^{\circ}$, incise I, of the 1988 Federal Constitution ${ }^{21}$ - which establishes that the minimum percentages to be applied yearly by the Union in public health actions and services would be defined through complementary law. An auspicious victory in this battle was the concession of an injunction in the direct action for unconstitutionality (ADIn 5.59522) reported by Minister Ricardo Lewandowski, asserting that the changes introduced by Constitutional Amendment no. 86/2015 to the minimum investment in the right to health "undeniably constrain the juridical stability and the progressive nature of federal funding of public health actions and services".

It will be regrettable that, having managed to establish the desired objective, we start to give in and loose unnecessary battles. We know where we wish to get to, lets not lose the path planned: we want a universal public health system capable of ensuring the right to health for all!

Sueli Gandolfi Dallari

Scientific Editor

\footnotetext{
${ }^{18}$ BRASIL. Decreto n. 591, de 6 de julho de 1992. International Acts. International Covenant in he Area of Economic, Social and Cultural Rights. Promulgation. Available at: <http://www.planalto.gov.br/ccivil_03/ decreto/1990-1994/d0591.htm>. Date accessed: 13 Oct. 2017.

${ }^{19}$ BRASIL. Decreto n. 3.321, de 30 de dezembro de 1999. Promulgates the Additional Protocolto the American Convention of Human Rights in the Area of Economic, Social and Cultural Rights "Protocol of San Salvador", concluded on November 17 1988, in San Salvador, El Salvador. Available at: <http://www.planalto.gov.br/ ccivil_03/decreto/d3321.htm>. Date accessed: 13 Oct. 2017.

${ }^{20}$ BRASIL. Lei Complementarn. 141, de 13 de janeiro de 2012. Regulates $\S 3^{\circ}$ of art. 198 of the Federal Constitution to rule on the minimum amounts to be applied yearly by the Union, States, Federal District and Municipalities in public health actions and services; determines the allocation criteria of resources to be transferred for health expenditure and the rules for monitoring, assessment and control of expenses with health in the three areas of government; repeals dispositions of Laws no. 8.080, of Septemebr 19 1990, and 8.689, of July 27 1993; and gives other provisions. Available at: <http://www.planalto.gov.br/ccivil_03/leis/LCP/Lcp141.htm>. Date accessed: 13 Oct. 2017.

${ }^{21}$ BRASIL. Constituição da República Federativa do Brasil de 1988. Available at: <http://www.planalto.gov. br/ccivil_03/constituicao/constituicaocompilado.htm>. Date accessed: 13 Oct. 2017.

${ }^{22}$ SUPREMO TRIBUNAL FEDERAL. ADI 5595 - Ação Direta de Inconstitucionalidade. Available at: <http://www. stf.jus.br/portal/processo/verProcessoAndamento.asp?incidente=5056708>. Date accessed: 13 Oct. 2017.
} 